\title{
Stakeholders' Participation and Its Effect on Water Projects Sustainability in Machakos County, Kenya
}

\author{
Patricia Goretti Ndinda Nzomo*, Dr. Lydia Gachengo ** \\ * Masters' Student, Department of Business Administration, School of Business, Kenyatta University, Kenya \\ ** Department of Management Science, School of Business of Kenyatta University
}

DOI: $10.29322 / I J S R P .11 .12 .2021 . p 12032$

http://dx.doi.org/10.29322/IJSRP.11.12.2021.p12032

\begin{abstract}
Many of the water projects within Machakos County that were started, funded and supported by international agencies as well as Constituency Development Fund (CDF) still failed to deliver water over a prolonged time with six out of ten becoming dysfunctional within three years of operations. Sustenance of projects is important hence this study considered stakeholders' participation. The main study objective was to investigate effect of stakeholder participation on water projects sustainability within Machakos County in Kenya. The study was anchored on participatory theory and employed descriptive research design and targeted project managers, water committee members and community elders as part of the project beneficiaries from the three completed water projects in Mavoko Constituency. The target population was stratified as per role and function that they handled and collection of primary data was through questionnaire that was first pilot tested to ensure its validity and reliability. SPSS was used for analysis that was descriptive producing frequencies, means and standard deviations and inferential statistics was conducted in terms of multiple regression and correlation to show relations and strength of the relationship between the two objectives. The study results showed that stakeholders' participation had positive and significant effect to water projects sustainability within Machakos County. The study concluded that stakeholders' participation led to improved water projects sustainability. To sustain water projects, the study recommends participation and involvement of stakeholders in the planning, designing, implementing, funding and managing of the projects.
\end{abstract}

Index Terms- Stakeholder Participation, Decision Making, Costsharing, Sustainability of water projects

\section{INTRODUCTION}

$\mathrm{W}$ ater is an essential part of human, animal and plant life and with its importance as an integral part of life hence the need for its continual supply. The governing units, donor bodies and the local communities must work together to provide this essential community, or else the risk of loss of life is an assured outcome. Therefore, calling for increased water sources like boreholes and water pans, and protection/conservation of natural water sources like rivers and lakes (Peterson, 2017). Since many parts of the world do not receive regular rainfall throughout the year and some communities cannot access natural water sources, then the concept of man-made water projects is conceived. According to Beratan (2020) any conceived project calls for its careful planning for all phase including sourcing for funds, seeking persons with technical know-how, managers to run the project and participation of all stakeholders.

In Africa, many of the countries face huge challenges in the supply of safe and clean water for drinking and use in homes of many of the citizenry. The situation is worsening as the African population keeps increasing over the years, plus many of the population are moving to urban areas where they worsen the need for piped water (Chowns, 2015). Only 56\% of the total population in Sub-Saharan Africa (SSA) is within the coverage of the water supply system and $48 \%$ of the rural populations rely on unimproved water sources for use and $22.5 \%$ of these rural water services are non-functional (Behailu, Pietila \& Katko, 2016). Most parts of Northern Africa struggle with constant droughts while many urban centers in Sub Saharan Africa suffer challenges in accessing clean and safe water. The poor urban populations have to survive on irregular water flow into their homes. According to Dos Santos, Adams, Neville, Wada, De Sherbinin, Bernhardt and Adamo (2017) half of the people in SSA countries cannot access safe water, fourteen countries have reported cases of severe water stress and another eleven nations will join the growing list of African nations by 2025 to have severity in water stress situation. Kenya as a nation also faces similar challenges in terms of water supply services that affect its sanitation and the health of its people. The situation has not improved despite considerable efforts in terms of investment by the national and county government and the donor community. The water supply situation is particularly bad in rural areas that lack any functional water supply system and the populated poor urban areas -the slums. Safe and clean water supply that is rated as a basis human right is not accessible and affordable to all (Oino, Towett, Kirui \& Luvega, 2015). As the population keeps growing at a fast rate, the more than 45 million people are unable to access safe water and those that can access the water; the supply is unreliable and inconsistent. According to the ratings of the public the Water Supply System (WSS) is rated as having performed poorly since only $60 \%$ of the urban people can access clean water and only $20 \%$ for those in slums or urban poor dwelling areas and access to clean water is estimated to be $40 \%$ for rural dwellers (Kwena, \& Moronge, 2015). Increased in investment and water projects had increased water supply but because of poor management and little or no maintenance of the water projects, some projects collapsed hence failure in attaining improved water supply rates. Project failure and collapse meant that water supply remains a challenge. As such, the people continue to suffer due to lack of water supply in 
terms of the health, well-being, growth and development (Cook, Kimuyu \& Whittington, 2016). Making it imperative to investigate how best to sustain water projects so as to ensure improved wellbeing and growth of the people. This study considered project planning in sustaining water projects.

Sustainability of the water projects means access to clean safe water throughout the year, having a functional water projects that has reliable water source and having a well maintained water project. Kisang (2019) shared that when it comes to sustaining water projects that are funded by donors, there is need to involve the locals by training to undertake minor repairs, participate in initial project activities and own the project for its sustenance. At the same time, Kinyua, Mwangi and Riro (2015) advocated for installing water users' associations that run then operations of the water projects and encourage ownership of the project in a way to ensure the project is sustainable. While Njogu (2018) revealed that community participation and engagement will led to better performance of the water projects and increase the chances for sustaining the water projects to continue serving the local communities for many years ahead.

Abrams (2018) reveal that sustenance is about continuity of a project to keep giving the same benefits to the project owners and beneficiaries. It is based on provision of the same function as when the project was launched and as stated in the plans and in the same quality or in an improved quality of the product. Nakagami, Kubota and Setiawan (2016) showed that for sustainability of projects to be achieved, factors like sufficient funds to cater for maintenance and repairs costs, provide well-trained and skill service providers who will design and deliver quality water projects. For sustainability of commissioned projects, Kwena (2015) noted that involving the project beneficiaries in the implementation increases feelings of ownership. The project planners and teams that implement the plans must include all the stakeholders at all the stages until its completion and commissioning.

To successful manage and sustain these water projects for supply of water to the people, there is need for proper planning and inclusion of stakeholders. When it comes to stakeholder participation, especially for public goods or community-based projects, then the decision-making process must involve all the stakeholders. During the planning phase, these stakeholders must be included and their opinion and views are sought and include in the master plan for the project ( $\mathrm{Li}, \mathrm{Ng} \&$ Skitmore, 2018). For water projects, it becomes essential to consider the local community members who are the beneficiary, the donors who will fund the project and administrative units both at the national and local levels. Stakeholder participation is a concept that included collective decision making, communication channels that will draw the support towards the project, labor sources both from skilled and un-skilled individuals, cost-sharing and stakeholder legitimacy for these projects.

Machakos County in the greater Eastern region faces drought on a yearly basis, since it receives annual rainfall rate of $500-600 \mathrm{~mm}$; thus its inhabitants are unable to access clean and reliable water supply. The national and county governments have come in to rescue the situation by pumping in money into water projects but the water projects are not sustainable. It then becomes necessary to explore to expose why the water shortage situation persists despite the many water projects in the region. According to Lilian and Mutiso (2019) two thirds (67\%) of water projects in the county do not serve the locals for five years or more, mostly ground to stop and the locals of the semi-arid area are left having to travel 20-30 kilometers in search of water. Some of the reasons explained for lack of sustainability include inadequacy of infrastructure that guide management and maintenance efforts, lack of inclusivity of the local communities, insufficient funding and no use of modern technologies. Other reasons include investing in new projects and no interest in maintaining the old water projects and also operating outside a framework of basic standards and regulation (Ministry of Water and Irrigation, 2019). Thus, the researcher investigated on stakeholder participation and how it affects the water projects sustainability in Machakos County, Kenya.

\section{LITERATURE REVIEW}

\subsection{Theoretical Review}

The study is underpinned by participatory theory is based on total involvement of the local population and other stakeholders in the creation of content, implementation of programs and development of policies that lead to changing the lives of people. The theory holds shaping and changing the future is left in the hands of the citizens (Carpentier \& Dahlgren, 2014). Thus, for enacting any changes there is need to participation of the local community members in the decision making process and guide the interventions. The participatory theory suggests the need to recognize the efforts, capacities and contribution of the locals since engaging them leads to higher chances of the project being on target and being sustainable in the long run (Fischer, 2012). Participatory theory is based on six principles for its effectiveness in inclusivity for high project output. The principles include equal partnership by all stakeholders; transparency by encouraging openness in handling all project activities and having open communication; power-sharing which allows balanced sharing of authority among the different project stakeholders; sharing responsibilities in the project; empowerment and cooperation. These principles can be employed in any project by encouraging partnership and engaging all stakeholders that will lead to success of the project and adoption of sustainability measures (Fischer, 2012).

Li, et al. (2018) share that participatory theory looks at stakeholder engagement and its collaboration with all stakeholders and the interest they have in the program or project. The stakeholders include donors of the project, staff, managers and community members and their ability to work together increases their individual capacity and competence leading to a successful project. Stakeholder engagement is also a tool that can be used educate the locals on maintenance of the project and easily manage any dissent and create synergy. This is because when the entire local community members, internal and external project stakeholders are included in planning, execution and maintenance and repairs for the water projects; then the projects can be sustained for a longer period. The theory attempts to describe that the views shared by stakeholders can help in sustainability efforts of the water projects.

\subsection{Empirical Literature}

Lorika, Lubwama and Namanya (2015) did a study on stakeholders' participation and project sustainability. The study 
was based on UNICEF child friendly schools and its quality in Moroto District in Uganda and its focus was establishing the influence that stakeholder participation had project sustainability. The findings revealed that when all the major stakeholders in the education sector participate in the project management it led to better performance of the projects. But the children and local leaders shared that their views and inclusion in the CFS project was not incorporated and this led to poor communication. When all pertinent stakeholders are not involved in a project, the outcomes are limited and there are challenges with sustaining the projects for long periods.

$\mathrm{Li}, \mathrm{Ng}$ and Skitmore (2018) investigation was on engagement of stakeholders and how it influences the evaluation of green buildings. The study concentrated on how sustainable post-occupancy operations affected project development. This study was conducted in China involving all the organization stake holders to prevent being dominated by other construction professionals. The finding indicated that stakeholder participation positively influences performance of construction project. The study also indicated that stakeholder integration helped that organization to designing team to improve their building design.

Mojtahedi and Oo (2017) conducted a study on how stakeholder attribute influences the organization performance of project. The focus of the study was on critical features that lead to proactive engagement of stakeholders in management. The finding indicated that stakeholder that has more power, attribute and legitimacy have effectively managed their disaster problems. The finding also established that socio-economic and transport infrastructure situations also affect the performance of this project.

Di Maddaloni and Davis (2017) studied the effect that local community stakeholders have on mega-projects. The study was conducted in Canada public infrastructure projects. The study concentrated on local community level project. The findings indicted that stakeholder management helps the stakeholder themselves to effectively manage control project resources. The study also indicted that engaging the local opinion on in the initiation phase increases performance of the project.

Kamalirad, Kermanshachi, Shane and Anderson (2017) investigation was on primary stakeholder communication and complex projects' outcomes. The concentration was on the stakeholders' internal communication forms within the terms of project owners and design. The study categorized the variable and conducted a survey focusing on the variable (internal communication) and their distribution among the construction active members. The study indicated that the project characteristic increases effective communication. The study concluded that number of designs, financial approval authorities and project scope clarification positively influence internal communication for the project stakeholders. The limitation of the study is that it fails to show the methodological approach used in conducting the research, thus evidently presenting a methodological gap.

\subsection{Conceptual Framework}

Stakeholders' Participation

- Decision-making

- Labor provision

- Project cost-sharing

- Monitoring and Evaluation

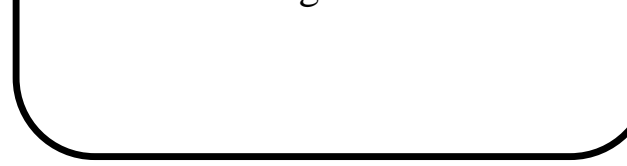

\section{Independent Variable}

Figure 1: Conceptual Framework

Source: Researcher (2021)

\section{RESEARCH METHODOLOGY}

The research design was descriptive one that was used as the blueprint to guide the researcher and as noted by Creswell and Creswell (2017) it is ideal in delving deep to answer questions on the 'why, what, when and how' of stakeholder's participation and sustainability of water projects. The researcher targeted project management committee members, project managers and locals who are beneficiaries of the three water projects in Mavoko Constituency, Machakos County. Primary data was collected using questionnaires, that were first pilot tested to ensure they

\section{Sustainability of Water}

Projects

- Functionality of water projects

- Continual water flow

- Year-round access to water

- Continued improvement

project

improvement

\section{Dependent Variable}

were valid and reliable and the data collection procedure was done by the researcher and trained research assistants.

Data analysis was done through cleaning, sorting, editing and entering the data in SPSS version 25.0 where analysis was then conducted. The researcher conducted descriptive analysis and obtained means, frequencies and standard deviation and also regressed the variables on each other and performed correlations to show the relations and magnitude between the variables. The findings were presented in tables, charts and discussions from the analysis.

The regression model was this:

$\mathbf{Y}=\boldsymbol{\beta}_{0}+\boldsymbol{\beta}_{1} \mathbf{X}_{1}+\varepsilon$ 
Where $\mathrm{Y}=$ Sustainability of Water Projects

$\mathrm{B}_{0=}$ Constant

$\varepsilon=$ error term

$\mathrm{X}_{1}=$ Stakeholders' Participation

\section{RESULTS AND DISCUSSIONS}

\subsection{Descriptive Analysis}

Table 1: Stakeholders' Participation

\begin{tabular}{lcc}
\hline Stakeholders' participation & Mean & $\begin{array}{c}\text { Std. } \\
\text { Dev. }\end{array}$ \\
\hline $\begin{array}{l}\text { All stakeholders are included in making } \\
\text { decisions concerning the water projects }\end{array}$ & 3.742 & .790 \\
$\begin{array}{l}\text { The local community members are trained to } \\
\text { undertake minor repairs on the water project }\end{array}$ & 3.203 & .786 \\
$\begin{array}{l}\text { The project leaders communicate to the local } \\
\text { community on each stage of the water project }\end{array}$ & 4.056 & .730 \\
$\begin{array}{l}\text { The water project employed skilled/unskilled } \\
\text { labor force from the local community }\end{array}$ & 4.166 & .916 \\
$\begin{array}{l}\text { All stakeholders monitor the project to ensure } \\
\text { it continuous to serve the communities }\end{array}$ & 3.899 & 1.105 \\
$\begin{array}{l}\text { The cost of the water projects is cost-shared } \\
\text { by different stakeholders (donors, national }\end{array}$ & 4.111 & .808 \\
$\begin{array}{l}\text { and county government) } \\
\begin{array}{l}\text { Contributions by different stakeholders is } \\
\text { welcomed for the success of the water project }\end{array}\end{array}$ & 4.120 & .967 \\
$\begin{array}{l}\text { Locals have the responsibility of maintaining } \\
\text { the project for sustaining it }\end{array}$ & 3.541 & .789 \\
$\begin{array}{l}\text { Stakeholders have greatly contributed to the } \\
\text { continuity of the water projects. }\end{array}$ & 3.667 & .958 \\
Overall Score & $\mathbf{3 . 8 5 6}$ & $\mathbf{. 8 7 2}$ \\
\hline
\end{tabular}

The Table 1 shows that on average stakeholder engagement affected sustainability of water projects at an overall mean score of 3.856 and standard deviation of .872 . These findings to the results of Lorika, et al. (2015) who shared that inclusion and participation of all major stakeholders in led to better performance of the projects. This was based on sound and better project management. Furthermore, Mojtahedi and Oo (2017) revealed that inclusion of stakeholders' who have power, attributes and legitimacy had greatly affected the management of projects.

Table 2: Sustainability of Water Projects

\begin{tabular}{lll}
\hline Sustainability of Water Projects & Mean & $\begin{array}{l}\text { Std. } \\
\text { Dev. }\end{array}$ \\
\hline $\begin{array}{l}\text { There is continuous water flow from the } \\
\text { water project for use by the local }\end{array}$ & & .864 \\
$\begin{array}{l}\text { community } \\
\text { Locals can access water from the project } \\
\text { all year-round }\end{array}$ & 4.312 & .815 \\
$\begin{array}{l}\text { Maintenance of the water projects make } \\
\text { them long lasting }\end{array}$ & 4.168 & .798 \\
$\begin{array}{l}\text { Upgrading of the water projects improves } \\
\text { their sustainability }\end{array}$ & 4.213 & .762 \\
$\begin{array}{l}\text { Monitoring and evaluating the project } \\
\text { ensures it remains functional }\end{array}$ & 3.700 & .801
\end{tabular}

This publication is licensed under Creative Commons Attribution CC BY. http://dx.doi.org/10.29322/IJSRP.11.12.2021.p12032
When quality standards of the projects

3.824 are maintained the water project lasts .890 longer

Overall Score

4.022 .821

Table 2 indicates that the overall mean score was 4.022 and variation of the responses at .821 for statements on sustainability of water projects. Just as Kwena (2015) shared that involving the project beneficiaries during the implementation increases feelings of ownership hence better handling of the project and thus higher cases of sustainability. Kisang (2019) talks of training locals to do minor repairs, using modern technologies that improve water project sustainability.

\subsection{Correlation Analysis}

Table 3: Correlation Analysis

\begin{tabular}{|c|c|c|c|}
\hline & \multicolumn{2}{|c|}{ Sustainability ofStakeholders' } \\
\hline & & Water Projects & Participation \\
\hline Sustainability & ofPearson & 1 & \\
\hline \multirow[t]{3}{*}{ Water Projects } & Correlation & & \\
\hline & Sig. (2-tailed & & \\
\hline & $\mathrm{N}$ & 101 & \\
\hline Stakeholders' & Pearson & .811 & 1 \\
\hline \multirow[t]{3}{*}{ Participation } & Correlation & & \\
\hline & Sig. (2-tailed & .000 & \\
\hline & $\mathrm{N}$ & 101 & 101 \\
\hline
\end{tabular}

**. Correlation is significant at the 0.01 level (2-tailed).

*. Correlation is significant at the 0.05 level (2-tailed).

Table 3 shows that stakeholder's participation had $r$ values of 0.811 and p-values of 0.000 an indication that the relation between the variables is positive and significant.

\subsection{Regression Analysis}

Table 4: Model Summary

\begin{tabular}{|c|c|c|c|}
\hline \multicolumn{4}{|c|}{ Table 4: Model Sur } \\
\hline ModelR & R Square & $\begin{array}{l}\text { Adjusted } \\
\text { Square }\end{array}$ & $\begin{array}{l}\text { RStd. Error of the } \\
\text { Estimate }\end{array}$ \\
\hline $\begin{array}{ll}.681^{\mathrm{a}} \\
\end{array}$ & .653 & .604 & 3.42406 \\
\hline
\end{tabular}

a. Predictors: (Constant), Stakeholders' Participation

Table 4 indicates that the coefficient of correlation results is at 0.681 indicating that the correlation of the variables is positive and noteworthy and the adjusted $\mathrm{R}$ was at 0.604 which means that any changes in sustainable water projects in Mavoko Constituency in Machakos County can be tracked to elements of stakeholder participation. Thus, $60.4 \%$ of sustainability of the water projects in Mavoko Constituency in Machakos County is due to stakeholders' participation. There is a residual effect of $39.6 \%$ that affects the sustainability of the water projects in Mavoko Constituency in Machakos County is by factors that have been excluded in this study's scope

Table 5: ANOVA

\begin{tabular}{|c|c|c|c|c|c|c|}
\hline \multicolumn{2}{|c|}{ Model } & Sum & & Mean & $\mathbf{F}$ & Sig. \\
\hline \multirow[t]{3}{*}{1} & Regressio & 137.523 & 4 & 34.913 & 2.979 & $.001^{\mathrm{b}}$ \\
\hline & Residual & 425.321 & 96 & 11.719 & & \\
\hline & Total & 562.844 & 100 & & & \\
\hline
\end{tabular}


a. Dependent Variable: Sustainability of Water Projects

b. Predictors: (Constant), Stakeholders' Participation

Table 5 shows $\mathrm{F}$ calculated is 2.979 which is greater than the F critical at $2.466(2.979>2.466)$ an indication that the model is a good fit and can be applied in the study. The p-value is 0.001 which is less than the set standard measure of 0.05 implying that stakeholders' participation had a significant effect to sustainability of the water projects in Mavoko Constituency of Machakos County.

Table 6: Regression Coefficient

\begin{tabular}{lll}
\hline Model & \multicolumn{2}{l}{ Unstandardized Coefficients } \\
\cline { 2 - 3 } & B & Std. Error \\
\hline (Constant) & 11.341 & 3.126 \\
Stakeholders' Participation & 5.783 & 1.340
\end{tabular}

a. Dependent Variable: Sustainability of Water Projects

The Resultant Equation takes the form of:

$\mathrm{Y}=11.341+\mathbf{5 . 7 8 3 X}_{1}$ Stakeholders' Participation (i)

Table 6 shows that at constant the sustainability of the water projects in Mavoko Constituency of Machakos County will be at 11. 341 and a unit increase of stakeholders' participation result in increase of sustainability of the water projects in Mavoko Constituency of Machakos County by 5.783 . The p-value results indicating that stakeholder participation had a significant effect on sustainability of water projects in Mavoko Constituency as the results are $0.00<0.05$

\section{CONCLUSIONS AND RECOMMENDATIONS}

\subsection{Conclusion}

The study established that participation of stakeholders led to positive and noteworthy effect in sustenance of the water projects. Stakeholder participation had elements like inclusion in decision making, local community members undertaking minor repairs, community members being employed in the water project, cost sharing the project costs, monitoring and maintaining the water project; leading to high sustainability of the water project. Thus, the study concludes that stakeholder participation led to improved sustainability levels of the water project

\subsection{Recommendations}

The study recommends that the water projects should employ stakeholder participation as a way to influence the sustenance of the water projects. All project stakeholders should be included in major and minor decisions, contribute in covering the costs, and take part in maintaining and doing minor repairs.

The study covered only three water projects and thus future studies should cover other water projects in the constituency and expand to other regions. The results from the adjusted coefficient of determination was $60.4 \%$ revealing that of sustainability of the water projects in Mavoko Constituency in Machakos County was due to stakeholder participation and the residual effect was of $39.6 \%$ of elements that were outside the scope of this study, as such future studies can cover these unexplained factors and broaden knowledge on sustainability of water projects.

\section{REFERENCES}

[1] Abrams, L. J. (2018). Understanding Sustainability of Local Water Services, 1998

[2] Behailu, B. M., Pietilä, P. E., \& Katko, T. S. (2016). Indigenous practices of water management for sustainable services: Case of Borana and Konso, Ethiopia. Sage Open, 6(4), 1-11.

[3] Beratan, K. (2020). Application of intervention design concepts to project planning for collaborative adaptive management of natural resources. Ecology and Society, 25(1)

[4] Carpentier, N., \& Dahlgren, P. (2014). The social relevance of participatory theory. Building Bridges, 37

[5] Chowns, E. (2015). Is community management an efficient and effective model of public service delivery? Lessons from the rural water supply sector in Malawi. Publie Administrationand Development, 35(4), 263-276.

Standardjzed Thum, P., \& Whittingtori, D. (2016). The costs of coping with Coeffigienter supply in rural Kenya. Water Resources Research, 52(2), 841Beta59.

[7] Creswell, J. W., צ̦60rqswell, J.(O0(02017). Research design: Qualitative, $.105^{\text {quantitative, and mixed-methods approches. Sage publications }}$

[8] Di Maddaloni, F., \& Davis, K. (2017). The influence of local community stakeholders in megaprojects: Rethinking their inclusiveness to improve project performance. International journal of project management, 35(8), $1537-1556$

[9] Dos Santos, S., Adams, E. A., Neville, G., Wada, Y., De Sherbinin, A., Bernhardt, E. M., \& Adamo, S. B. (2017). Urban growth and water access in sub-Saharan Africa: Progress, challenges, and emerging research directions. Science of the Total Environment, 607, 497-508.

[10] Fischer, F. (2012). Participatory governance: From theory to practice. The Oxford handbook of governance, 457-471.

[11] Kamalirad, S., Kermanshachi, S., Shane, J., \& Anderson, S. (2017). Assessment of construction projects' impact on internal communication of primary stakeholders in complex projects. In Proceedings for the 6th CSCE International Construction Specialty Conference

[12] Kinyua, M. M., Mwangi, A. W., \& Riro, G. K. (2015). Financial Management Aspect on Sustainability of Community Managed Water Projects in Kieni West District, Nyeri County, Kenya.

[13] Kisang, K. A. (2019). Factors Influencing Sustainability of Donor Funded Water Projects in Kenya; a Case of Turkwel Ward, Lorugum Location, Turkana County, Kenya (Doctoral dissertation, University of Nairobi)

[14] Kisang, K. A. (2019). Factors Influencing Sustainability of Donor Funded Water Projects in Kenya; a Case of Turkwel Ward, Lorugum Location, Turkana County, Kenya (Doctoral dissertation, University of Nairobi)

[15] Kwena, R., \& Moronge, M. (2015). Determinants of sustainability of rural water projects in Kenya: a case study of the Netherlands Development Organisation (SNV) supported water schemes in Kajiado County. The Strategic Journal of Business and Change Management, 2(2), 124.

[16] Li, H., Ng, S. T., \& Skitmore, M. (2018). Stakeholder impact analysis during post-occupancy evaluation of green buildings-A Chinese context. Building and Environment, 128, 89-95

[17] Lillian, N., \& Mutiso, J. (2019). Determinants of sustainability of water projects at Machakos County in Kenya. Journal of Entrepreneurship and Project Management, 4(1), 118-138.

[18] Lorika, M. L., Lubwama, A. N., \& Namanya, A. M. (2015). Stakeholders Participation and Project Sustainability among Development Agencies in Uganda. A Case of Unicef Child Friendly Schools/Quality Education Project in Rural Government Primary Schools, Nadunget Sub County, Moroto District (Doctoral dissertation, Uganda Management Institute).

[19] Mojtahedi, M., \& Oo, B. L. (2017). Critical attributes for proactive engagement of stakeholders in disaster risk management. International Journal of Disaster Risk Reduction, 21, 35-43.

[20] Nakagami, K. I., Kubota, J., \& Setiawan, B. I. (2016). Sustainable water management (p. 189). Springer: Singapore.

[21] Njogu, M. J. (2018). Influence of Community Participation on Project Performance. A Case of Ruiri Water Projects, Meru County, Kenya. Unpublished MA project. University of Nairobi

[22] Oino, P. G., Towett, G., Kirui, K. K., \& Luvega, C. (2015). The dilemma in sustainability of community-based projects in Kenya. Global journal of advanced research, 2(4), 757-768 
[23] Peterson, J. M. (2017). Water-energy-food nexus-commonalities and differences in the United States and Europe. In Competition for Water Resources (252-258).Elsevier

\section{AUTHORS}

First Author - Patricia Goretti Ndinda Nzomo, Masters' Student, Department of Business Administration, School of Business, Kenyatta University, Kenya

Second Author - Dr. Lydia Gachengo, Department of Management Science, School of Business of Kenyatta University 